\title{
Institutionalization of Political Parties on Post New Order Authoritarianism and It's Implications for Indonesian Democracy
}

\author{
La Ode Muhammad Muliawan', Imam Sumantri ${ }^{2}$ \\ 1 Department of Political Studies, Faculty of Political and Social Science, Universitas Bangka \\ Belitung, Kampus Terpadu UBB Balunijuk, Gd. Babel 1 Jl. Kampus Peradaban Balunijuk, \\ Merawang, Bangka, Bangka Belitung, Indonesia 33172 \\ 2 Boyolali's Student Association (KMB) Yogyakarta, Jl. Sosio Yustisia No.1, Karang Malang, \\ Sleman, Yogyakarta 55281
}

Corresponding author: odeubb@gmail.com

\begin{abstract}
The article aims to explain how the institutionalization of political parties in Indonesia after the collapse of New Order regimes and how it affects the democratization in Indonesia. This paper used a literature research method with a qualitative descriptive research type. The results showed that political parties in Indonesia after the authoritarianism regime, it had not been institutionalized and was even far from it if it was compared to the magnitude level its current problem. Political parties are trapped on long term internal conflict of interest, drained their energy, and continued until now. Moreover, the depth oligarchies pattern in its management is getting worse by the personalized figure, and the dominance of the party's management from the central, thus the conclusion points out that political party is merely the sub-ordinates of elite's interest. The result indicated that political parties have failed to play an essential role in supporting consolidated democracy since they were busy and distracted by their internal problems. Therefore, how long Indonesia will be in the transition phase of democracy depends on how severe political parties take reforms.
\end{abstract}

Article Info :

Article history :

Received: July 11, 2020

Revised: August 24, 2020 Accepted:September 21, 2020

Keywords: democracy; institutionalization; political parties

\section{INTRODUCTION}

This paper tries to examine how political parties are institutionalized in postreform Indonesia. The strategic position of political parties in a democratic state was once conveyed by Max Weber as the golden child of democracy. The presence of political parties as pillars of democracy has the logical consequence that their presence is a precondition for sustained democracy. The absence of political parties can endanger the function of democracy, and the fully-functioned democracy depends and determines by the presence of political parties. 
With various pivotal functions, political parties as a pillar of democracy should be able to form an ideal forum or institution that can support the running of an ideal and sustain democracy. Huntington has also conveyed a similar concept that one of the main indicators towards a consolidated democracy requires political party institutions and elections as the essence of democracy (Huntington, 1968).

The reformation 1998 is a golden moment for political parties to reform themselves. In a crisis, the performance of political parties that are efficient and effective in helping crisis management can be a channel to increase public trust (Haughton \& Deegan-Krause, 2015; Roberts, 2017; Vasilopoulou, 2018; Wonka, 2016). Political parties can use this momentum in addition to restoring their poor image due to a lousy representation function as well as removing their political legitimacy in society.

The changes in the electoral system in Indonesia are quite significant after the reformation. It should provide space for political parties to maximize their function and performance. However, the changes in the electoral system that occurred during the democratic period have an impact on the performance of weak political parties (Aminuddin, 2016). Several studies on parties also show that the process of institutionalizing political parties is still weak, for example, as in the findings (Mahardika, 2019; Romli, 2016). It is due to the strength of figures who are overused as benchmarks within the election (Tan, 2002). Especially nowadays, the cost of politics in Indonesia is the very high category; the implication is there is a concern for the process of democratic consolidation (Dwipayana, 2009). The high political costs are inseparable from the low party-ID due to the failure of the interest agrarian function demonstrated by political parties (Sihidi, Khanifah, \& Romadhan, 2019; Muhtadi, 2013).

On the other hand, strengthening democracy after reformation can create new problems for political parties, especially Islamic political parties. It is due to various factors, such as the history of Islamic parties which have only been used as political tools, causing divisions among Muslims (Yumitro, 2013). The most well-known phenomenon of Indonesia is the election process in DKI Jakarta, which involves a substantial religious issue between candidates. One of the Islamic political parties that still existed and had a reasonably good institutionalization at that time was Prosperous Justice Party (PKS) with a powerful personal and religion-based (Hidayat, 2017). It is necessary to implement new actions as the stance of the opposition party; similar to Indonesian Democratic Party of Strugle (PDIP) has done in the election of 2004 to balance and strengthen democracy by political parties. However, this also does not become an adequate solution that runs well because of the coalition factors that do not have the same ideology and internal solution (Admojo, 2016).

The latest findings in the studies of political parties in Indonesia after the Reforms era shows the different symptoms compared to the Old and New Order era. The tension of ideological battles between political parties throughout the long period of Old and New Order is getting weaker. Political parties in Indonesia no longer compete with each other but tend to form cartels (Ambardi, 2009; Mietzner, 2013; Lestari, 2017; Slater \& Simmons, 2013). The choice to compete with each other for parties is no longer interesting since the formation of coalitions between parties brings more benefit to access national resources easily. Elections taken from political parties cannot ultimately be made as benchmarks to determine who is the party that makes the government and 
who organizes the relation. Political parties fight it out, and afterwards, they have united by interests in a large container known by Ambardi as the "rainbow coalition".

Then, how far political parties in Indonesia can play their role as the most formal institution and the core of modern democratic government after the down of authoritarianism regime. This question is crucial considering the institutionalization or institutionalization of political parties as to the primary component that determines the consolidation of democracy in addition to the institutionalization of elections. Mainwaring and Scully staged the institutionalization of political parties in four dimensions (Mainwaring \& Scully, 1995; Mainwaring, 2016). First, the stability of competition between parties which refers to changes in the number of political parties participating in the election. The tendency of changes in the number of political parties participating in the elections shows the low level of institutionalization of political parties. Second, the depth of party roots in the society which refers to the stability of support obtained by political parties in each election. Third, political actors are legitimate for political parties. Fourth, party organizations are not subordinated to the interests of leaders or a handful of elites.

Besides, Huntington also set aspects that can be used as a reference to see whether a political party has been institutionalized or not, namely adaptability, complexity, autonomy and coherence (Huntington, 1968). Taking into considering the internal and external aspects Randall and Svasand stated four elements of the institutionalization of political parties, namely systemness, decisional autonomy, value infusion and reification (Randall \& Svåsand, 2002). In comparison, the Netherlands Institute for Multiparty Democracy (IMD) formulates five elements of the institutionalization of political parties, namely: the development of internal democracy, internal integrity, political identity, organizational resilience and campaign capacity (IMD, 2006).

Concerning to the analysis, the author uses those elements to discuss the extent of institutionalized Indonesian political parties. Therefore, this paper will focus on elements of internal integrity (cohesiveness) and changes in the number of political parties (volatility), the depth of the party's roots in society, and parties as a subordinate to the interests of the elite. Furthermore, the results of the study of the institutionalization of political parties in Indonesia after the reformation will be useful to discover how far the political parties can contribute to the development of democracy in Indonesia.

This article's review differs from several previous studies related to the institutionalization of political parties in Indonesia. First, this study focuses on the institutionalization process of political parties from internal conflicts over recommendations for regional head elections due to centralization of power (Mangestuti, 2010; Primadi \& Purwaningsih, 2019). Second, the emergence of patronage and clientelism as an obstacle to the institutionalization of political parties as in the findings (Firmadi \& Purwaningsih, 2017) which caused the failure of the Democratic Party (PD) political party machine to work optimally so that party votes decreased in the 2014 Lampung Legislative Election. A similar study conducted by Ridha (2016), who finds out the big dilemma in the institutionalization of Functional Groups Party (Golkar) at the local level because of the strength of clan politics. Fourth, 
the primary key to the process of institutionalizing political parties is the improvement in the aspects of funding, regeneration and strengthening of ideology (Ristyawati, 2019).

\section{METHOD}

This study used library research methods to explain the institutionalization of political parties in Indonesia and its implications for democracy. This method is a series of activities related to collecting library data and processing research materials. Observation of library research carried out with in-depth observations on studies of crucial information on the topic under study. The data and facts in the information considered to represent the object of research.

Types of research used descriptive qualitative methods to explain the institutionalization of political parties in Indonesia and their implications for democracy. This method is chosen based on its strengths in explaining a problem in more detail. Data collection carried out using desk study techniques; by examining a variety of literature, articles and related documents relating to the issue of institutionalization of political parties in Indonesia.

Furthermore, the data obtained through various literature, articles and documents then analysed by the data reduction. Data reduction means sorting the essenntial data related to research. The aim is to produce a conclusive description regarding the institutionalization of political parties in Indonesia and its implications for democracy.

\section{RESULTS AND DISCUSSION}

\section{Internal Integrity and the Shifting Amount of Political Parties (Volability)}

In general, two main characters are identical to political parties in Indonesia after the New Order. Firstly, the low internal cohesiveness of political parties. In the Reform era that developed after the fall of the Soeharto regime, the rifts and divisions that occurred in the political parties became increasingly plural. Almost all political parties in Indonesia experience internal conflicts for various reasons. If during the New Order era party divisions or internal conflicts only occurred in two political parties; Indonesian Democratic Party (PDI) and United Development Party (PPP). The 1998 political reforms that opened space for the formation of new political parties succeeded in creating new conflicts spaces beside the two parties. The National Awakening Party (PKB) case, for example, is an example of a party with a low level of internal integrity. The party continues to be plagued by conflicts even some time since it was founded. In 2001, the conflict in this party involved Matori Abdul Jalil as Chairperson of PKB's Tanfidz Council and Chairperson of the PKB Shura Council.

The ripple in the party has caused by the presence of Matori Abdul Jalil in the Special Session of the People's Consultative Assembly with the agenda of impeachment on President Gus Dur. This episode of conflict ended with the dismissal of Matori Abdul Jalil as Chairman of the PKB Tanfidz Council and even sacking as a party member. Furthermore, in 2008 the conflict in the body of the Nahdliyin party also occurred when Muhaimin Iskandar as Chairman of the Tanfidz Council was fired from his post (Noor, 2015). These two episodes of conflict resulted in the birth of two dual stewardships, and 
for the last conflict, the PKB version of Muhaimin Iskandar succeeded in getting legality after being declared victorious by the Ministry of Law and Human Rights acknowledging its organization (Haboddin, 2011).

In the PDI-P case, the presence of Megawati as a very dominant patron in the party bearing the bull could not close the gap for internal conflict within the party. A low level of cohesiveness was evident in a few moments, especially in the early decades after the formation of this party. This chaos was motivated by the struggle for the position of party chairperson between the Megawati camp and the Eros Djarot and Dimyati camps in 2000 at the party congress in Semarang and between the Megawati camps facing the reform camps fronted by the Guruh Soekarno Putra, Arifin Panigoro, Laksamana Sukardi and Sophan Sophian at the congress in Bali in 2005 (Haboddin, 2011).

PPP also experiences the disunity that led to the birth of dualism in management. A series of prolonged internal conflicts have disrupted parties throughout the New Order era. This chaos began when PPP Chairperson Suryadarma Ali attended the Gerindra Party campaign, which seen as a betrayal by PPP cadres. Disunity within the party bearing the Kaaba continues with the formation of two factions convinced that the Dzan Farisz and Romahurmuzi camps are mutually claiming each other's legitimacy (Sadewo, 2014; Ramadhan, 2014). Both sides each chose to take legal action to justify their respective claims (Tempo.co, 2016; Tempo.co, 2017), including fighting over positions to get government support.

Chaos and internal conflict also experienced by the PKS. It considered as the best party in carrying out regeneration and including parties far from the issue of division, especially in the early decades after it founded. PKS experienced internal conflict and ended in a split which caused many party cadres and management to resign (Hermawan, 2018; Fauzi, 2018; Kirom, 2019). This party chaos began when the change of management, which was an Anis Matta loyalist by Sohibul Iman as the PKS new President. Chaos became even more acute when the dismissal of Fahri Hamzah as Anis Matta's loyalist who would have negotiated to overthrow the leadership of Sohibul Iman (Tempo.co, 2018).

Besides, Golkar as a party which during the New Order was a dominant force because it became the political vehicle of the Soeharto government, which was far from internal conflicts began to struggle. The fall of Soeharto from the stacked of national leadership which during the new order played a role as a patron for all Golkar politicians and cadres left the party vulnerable to conflict. It noted that Golkar had experienced chaos and even division several times. In 1998 the Golkar National Conference became a battleground for civilian representatives in command of Akbar Tanjung against military representative Edi Sudradjat in bringing about the position of party leader. The conflict escalated again in 2004 when the defeated Golkar decided to support Wiranto-Salahuddin Wahid as a pair of candidates for President and Vice President in the first round of the presidential election and supported Megawati-Hasyim Muhzadi in the second round, but at the same time, Jusuf Kalla as an adviser to the Golkar party running for Vice-Presidential Candidate accompanied Susilo Bambang Yudhoyono (SBY) and successfully won the election (Nathaniel, 2019; Budiatri et al., 2017). In 2014 the Golkar Party heated up with the formation of two factions, each of 
which supports Aburizal Bakrie and Jusuf Kalla. The heat tension returned to peak after being triggered by Agung Laksono's camp to reject Aburizal Bakrie as party leader, which led to the formation of dual management of the Golkar party (Nathaniel, 2019).

The tendencies and even the characteristics of post-reform political parties that are prone to conflicts and internal rifts show a different symptom from the new order. During the New Order, internal rifts had based on the political design of the government which imposed a simple party system with three parties at the same time continuing to maintain internal conflicts of political parties (Lay, 2019; Haris, 2014). Conflict and division of political parties after Suharto occurred more based on the struggle of the interests of each element and faction within the party. It is discovered in a series of political party divisions as is the experience of Golkar, PKB, PPP, PDIP and PKS.

Practically, the chaos that occurred within the party has dominated by leadership struggles. In the case of PKS, ideological issues were one of the triggers. It is certainly disappointing, and it indicates the negative symptoms considering that history has recorded that internal conflicts and divisions in the body of political parties in Indonesia made ideological differences as the cause (Noor, 2015).

Second, the change in the number of political parties participating in the election from one election period to another election period. As an implication of the reform of Indonesia's political life after authoritarianism, the space for participation for all social and political forces, including political parties, is opened. This space is used by various groups to establish new parties and try their luck in the power struggle. As a result, the number of Indonesian political parties increased significantly in the early years of reform.

Table 1. The Number of Political Party in Indonesia on Post Reformation Era

\begin{tabular}{llll}
\hline $\begin{array}{l}\text { Year } \\
\text { Election }\end{array}$ & $\begin{array}{l}\text { Total of Political Parties } \\
\text { Being Registered in Participate } \\
\text { Ministry of Law and in Election } \\
\text { Human Rights }\end{array}$ & $\begin{array}{l}\text { Passed the } \\
\text { Parliamentary } \\
\text { Threshold }\end{array}$ \\
\hline 1999 Election & 148 & 48 & 19 \\
2004 Election & 50 & 24 & 16 \\
2009 Election & 51 & 38 & 9 \\
\hline 2014 Election & 73 & 12 & 10 \\
\hline 2019 Election & 73 & 16 & 9 \\
\hline
\end{tabular}

Source: From Various Sources

The Table 1 shows the data prior to the 1999 election, as many as 148 parties had registered as legal entities at the Ministry of Law and Human Rights. Of the total 48 
political parties were eligible to contest the 1999 general election. This number continued to experience significant changes in the 2004 election period. More than 200 parties had registered with the Ministry of Justice and Human Rights, and 50 of them had also registered as Legal Entities. Of the total number of parties that participated in the verification, 24 political parties had declared to have passed as participants in the 2004 elections (Haris, 2014). The number of election participants increased drastically in 2009 by 38 parties compared to the 2004 general election of only 24 parties. Meanwhile, the number of political parties with legal entities did not increase significantly. Finally, in the 2014 and 2019 elections, the number of political parties participating in the election changed to 12 and 16 political parties.

The change in the number of political parties which is very dynamic is considered interesting after several things that influenced the post-1998 reform era. First, in the early periods after the fall of authoritarianism, the new order opened both political and formal space which made it possible to form political parties effortlessly, and this had proven by the establishment of political parties in huge numbers. Second, the increase in the number of political parties in Indonesia after the reform had also contributed by the internal fragility of political parties. Political parties fail to maintain cohesiveness as a result of the failure to manage friction or internal conflict through an ideal conflict resolution mechanism. Many political parties experienced divisions and led to the formation of new parties by mobilizing politicians from one old party to the new party.

After the collapse of the New Order's authoritarianism, political parties in Indonesia had frequently involved in internal battles including factions within the party. A situation was similar to the early days of independence where political battles confront not only one party with another but also between factions within the same political party (Feith, 2006). Widespread internal conflict within the party body that is not accompanied by an ideal institutionalization of conflict management results in factionalism which leads to the division and formation of new parties. However, the absence of an ideal conflict management development is not the only factor causing the mushrooming of new parties. External factors such as the effectiveness of formal legal rules, as well as a combination of open proportional systems, direct election systems and extreme multi-party systems also contribute to the increasing number of political parties in Indonesia (Budiatri et al., 2017).

Table 2. New Parties as Result of Disintegrated Political Parties

\begin{tabular}{ll}
\hline The "Filial" Party & $\begin{array}{l}\text { New Party Resulted from Disintegrated Political } \\
\text { Parties }\end{array}$
\end{tabular}

\begin{tabular}{ll}
\hline GOLKAR & HANURA, GERINDRA NASDEM, MKGR, PKPI, PKPB \\
PDIP & PITA, PNKB, PDPR, PDP \\
PAN & PMB \\
PKB & PKNU, PKB
\end{tabular}




\section{DEMOKRAT}

PPP

\section{PNKRI}

PP, PBR

Sources: (Budiatri et al., 2017)

The Table 2 shows a map of political parties in Indonesia after the new order that had formed as a result of internal party divisions. Practically almost all political parties, including parties which had already established their existence in the Indonesian political arena, experienced a split. Golkar, PDI-P and PPP, which were political parties that were very explicit during the reign of the New Order, were transformed into mothers of new parties born after the reformation. Nevertheless, only the Golkar party can evoke the parties (Hanura, Gerindra and Nasdem) that politically have a significant impact on Indonesian politics in every post-reform election. It is understandable considering that Golkar is home to politicians who have significant resources through their relations with the state during the New Order. The phenomenon of internal conflicts on political parties in Indonesia after the reformation, which in many cases emerge many new political parties in which it shows the weakness of party institutionalization in Indonesia.

\section{The Depth of Party Roots}

The depth of party roots is one dimension to measure how well political parties have institutionalized in a country. This measurement is suitable based on the consistency of voter preferences of a political party from one election to another. The higher the number of electoral volatility or the aggregate change of choice from one political party to another, the weaker the level of party institutionalization in a country. Conversely, the low electoral volatility will increase the level of political party institutionalization. Thus, electoral volatility provides an overview of the depth and quality of the relationship between parties and voters.

In a multi-party system, the first post-reform elections in 1999 are followed by more than 40 political parties that failed to produce a majority in parliament. PDIP as the party that won the election with $33.76 \%$ votes did not become the majority force even though they got the largest percentage in parliament. In general, the power in parliament based on the 1999 election results has fragmented in 19 political parties that succeeded in gaining seats in the parliament.

Table 3. Votes for Political Parties in the 1999 Election

\begin{tabular}{lll}
\hline No & Political Party & Percentage \\
\hline 1 & PDIP & $33,74 \%$ \\
2 & Golkar & $22,44 \%$ \\
3 & PPP & $10,71 \%$ \\
4 & PKB & $12,61 \%$ \\
5 & PAN & $7,12 \%$ \\
6 & PBB & $1,94 \%$
\end{tabular}




$\begin{array}{lllr}7 & \text { PK } & 1,36 \% \\ 8 & \text { PKP } & 1,01 \% & \\ 9- & \text { PNU, PDKB, PBI } & 0,64 \%, & 0,52 \%, \\ 11 & & 0,34 \% & \\ 12- & \text { PDI, Partai Persatuan, PDR, PSII, PNI Front } & 0,33 \%, 0,62 \%, 0,40, \\ 19 & \text { Marhaenis, PNI Masa Marhaenis, Partai IPKI, } & 0,43 \%, & 0,35 \%, \\ & \text { Partai Kebangkitan Umat } & 0,33 \%, & 0,31 \%, \\ & & 0,28 \% & \end{array}$

Source: Processed from KPU Official Data

From the table above (Table 3 ) it can shows that political parties that have more than $1 \%$ vote percentage were only eight parties. The Golkar Party won $22.44 \%$ of votes, PPP 10.71\%, PKB 12.61\%, PAN 7.12\%, PBB 1.94\%, PK 1.36\%, PKP 1.01\% and PKP $1.01 \%$. The results of the second post-reform election held in 2004 were not much different from the election in the previous period. With 24 political parties participating, the 2004 elections resulted in a highly fragmented political force with 16 parties gaining seats in parliament.

Table 4. Votes for Political Parties in the 2004 Election

\begin{tabular}{lll}
\hline No & Political Parties & Percentage \\
\hline 1 & Golkar & $21,62 \%$ \\
2 & PDIP & $18,31 \%$ \\
3 & PPP & $8,16 \%$ \\
4 & Demokrat & $7,46 \%$ \\
5 & PAN & $6,41 \%$ \\
6 & PKB & $10,61 \%$ \\
7 & PKS & $7,20 \%$ \\
8 & PBR & $2,60 \%$ \\
9 & PDS & $2,14 \%$ \\
10 & PBB & $2,62 \%$ \\
11 & PPDK & $1,16 \%$ \\
12 & Partai Pelopor & $0,79 \%$ \\
13 & PKPB & $2,12 \%$ \\
14 & PNI Marhaenisme & $0,80 \%$ \\
15 & PKPI & $1,26 \%$ \\
16 & PPDI & $0,75 \%$ \\
\hline
\end{tabular}

The Table 4 shows the 2004 election results won by Golkar with 21\% votes despite one per cent decrease below the result in the 1999 election which at 22\%. PDIP, which was the winner of the 1999 election, suffered a significant decline with their 
votes. In the 2004 election, PDIP gained 18.31\% votes, a vast decrease when compared to the previous general election which at $33.74 \%$ votes. It is possible to occur because of the increasing number of votes gained by some political parties such as PK which changed to PKS, PPP and the emergence of Democratic Party (PD) as a new party that gained $7.46 \%$ valid votes.

The third post-reform election held in 2009 brought Democrats (PD) as the winning party. Participated by 38 political parties, the 2009 election led nine political parties to obtain seats in parliament after their numbers of votes meeting the parliamentary threshold requirements.

Table 5. Votes for Political Parties in the 2009 Election

\begin{tabular}{ccc}
\hline No & Political Parties & Percentage \\
\hline 1 & Demokrat & $20,81 \%$ \\
2 & Golkar & $14,45 \%$ \\
3 & PDIP & $14,01 \%$ \\
4 & PKS & $7,89 \%$ \\
5 & PAN & $6,03 \%$ \\
6 & PPP & $5,33 \%$ \\
7 & PKB & $4,95 \%$ \\
8 & Gerindra & $4,46 \%$ \\
9 & Hanura & $3,77 \%$ \\
\hline
\end{tabular}

Source: Processed from KPU Official Data

A shocking change (see Table 5) compared to the results of the previous election was the declining of the votes for Golkar and PDIP was significant. Golkar which won in the 1999 election with $22.44 \%$ votes and gained $21.62 \%$ in the 2004 election was decreased significantly to $14.45 \%$. Then PDIP which won the 1999 election with more than $30 \%$ votes and gained $18.31 \%$ votes in the 2004 election, also suffered the same thing where their votes had decreased to $14.01 \%$.

PD victory in the 2009 election is so phenomenal considering their position as a new party. If in the 2004 election Democrat was only gained $7.46 \%$ vote and then increased significantly in the next election to $20.81 \%$. Two reasons can explain the phenomenal emergence of Democrats as the winner of the election. First, SBY's appeal as an incumbent whose act as a symbol for the party itself. As a President, SBY is a magnet for voters mainly due to the appreciation of the government's performance during the first period of his administration. Second, the other parties' failure to treat their respective constituents which then caused them to lose support in a huge number (Yuda, 2009).

The 2014 election participated by 12 political parties of 16 political parties that passed administrative verification. This number does not include the three local political parties that also participated in the 2014 general election. From the 12 political parties that participated in the 2014 election only ten parties managed to get a seat in 
parliament whereas the remaining two parties, namely PBB and PKPI unable to pass the parliamentary threshold. PDIP getting the most votes with $18.95 \%$ votes followed by Golkar with $14.75 \%$ votes, Gerindra with $11.81 \%$ votes, Democrats with $10.19 \%$ votes, then followed by PKB, PAN, PKS, Nasdem, PPP and Hanura. PDIP managed to increase its votes from $14.01 \%$ in the 2009 election to $18.95 \%$, while Golkar only managed to get a slight change of votes compared to the previous election. It is different from Democrats whose votes are falling compared to the previous election.

Table 6. Votes for Political Parties in 2014 and 2019 Elections

\begin{tabular}{llll}
\hline No & Political Parties & 2014 Election & 2019 Election \\
\hline 1 & PDIP & $18,95 \%$ & $19,33 \%$ \\
2 & Golkar & $14,75 \%$ & $12,31 \%$ \\
3 & Gerindra & $11,81 \%$ & $12,57 \%$ \\
4 & Demokrat & $10,19 \%$ & $7,77 \%$ \\
5 & PKB & $9,04 \%$ & $9,69 \%$ \\
6 & PAN & $7,59 \%$ & $6,84 \%$ \\
7 & PKS & $6,79 \%$ & $8,21 \%$ \\
8 & Nasdem & $6,72 \%$ & $9,05 \%$ \\
9 & PPP & $6,53 \%$ & $4,52 \%$ \\
10 & Hanura & $5,26 \%$ & $1,54 \%$ \\
\hline
\end{tabular}

Source: Processed from 2019 KPU Official Data

The table above (Tabel 6) shows a very significant vote shift in the 2019 election. Parties that received significantly high numbers of votes in the previous elections suffered a declining in support from voters. People's Conscience Party (Hanura) and Democrats (PD) were the ones that suffered the most significant decline in support from voters. It is understandable considering that Hanura has struck by internal conflicts between their elites that made the party lose enough energy to face the 2019 Election. In Democrats' case, the trend is even worse considering that in the 2009 election they gained more than $20 \%$ votes but then only got $7 \%$ support in the 2019 election.

The data on the results of the five post-reform elections above confirms that political parties in Indonesia after the new order authoritarian regime do not have deep roots in society. Political parties do not have a fixed mass base from one election period to another. Therefore, the race of political party support is very dynamic in each election period. PDIP, as the winner of the 1999 election with more than $30 \%$ votes, experienced strong support decline the 2004 election to $18 \%$. That number continues to fall in the 2009 election to $14 \%$, but it has increased again in the last two elections. Golkar as a senior and large party during New Order managed to get $22.44 \%$ votes in 
the 1999 election and fell to $21.62 \%$ in the 2004 election despite winning the election.

Furthermore, in the 2009 election, their votes fell to $14.45 \%$ and in the 2014 election only managed to get a slight change to $14.75 \%$. These numbers have dropped again in the 2019 election to $12.31 \%$. Likewise, Democrats participating in their first election in 2004 and managed with a total vote of $7.46 \%$, which had classified as a massive success for a new party. Then in their second participation, they won the 2009 election with a total vote of $20.81 \%$ which is practically almost three times more than their result from the previous election. However, their support decreased significantly in the last two elections, which were $10.19 \%$ in the 2014 election and $7.77 \%$ in the 2019 election. The instability of vote result in every election had also experienced by other parties such as PKS, National Mandate Party (PAN), Gerindra, PKB, PPP, Hanura and Nasdem. However, PKS is an interesting case because they got the amount of support that is relatively more stable from one election to another.

\section{Party as A Subordination of Elite Interests}

The tendency is very easy to find when observing the management of political parties in Indonesia is the thickness of oligarchy practices, personalization and centralization of organizational structure. The phenomenon which Winters mentioned as a form of indigenous oligarchs' success in investing enormous resources in political parties (Winters, 2011), The effect is predictable, political parties managed practically similar to private institutions where only a handful of party elites have a dominant role. The study of the presence of a group of people who have more dominant roles in political parties is not new. Robert Michels had already identified this in Iron Law Oligarchy about the dominance of the authority of a handful of elites in political parties.

Michels' allegory "Le Parti C'est Moi” which means the party is me in which this expression indicates its basis in the practice of managing political parties in Indonesia. We can simply identify political parties just by identifying their party figures. The vital personalization of figures such as Megawati Soekarno Puteri for PDIP, Susilo Bambang Yudhoyono for Democrats and Prabowo for Gerindra caused these figures to become identified as the party itself. The emphatic position of these figures in these parties tends to put the will and personal expectations into the will of the party and even can be be understandable as an ideology for party activists and sympathizers. Megawati's strong figure for PDIP became a symbol for the party bearing a bull as their logo and even became the party's character. Almost all essential and crucial decisions in the party stemmed from Megawati as the final policymaker. It also the case with SBY and Prabowo for Democrats and Gerindra. Both play a very central role in making strategic party policies.

The last thing that characterizes the management of political parties in Indonesia is the institutionalization of the political party central management's dominance. Practically almost all political decisions become an authority that can only be controlled by the executives at the central level and even in a narrower context; it only determined by a handful of elites in the party. The dominance of DPP in Indonesia political parties that allows party elites to have exclusivity in strategic policymaking institutionalized in the AD / ART of each party (Budi, 2013). Critical issues related to the candidacy for presidential candidates, regional head candidates and the appointment of legislative 
candidates who will be supported by the party are under the absolute authority of the executive at the central level. Parties as PDIP, Democrats and Gerindra, it depends on the blessing of the figure as the symbol of the party.

The centralized organizational structure of political parties by the construction of laws and regulations causes the lower level party organizational structures to lose their autonomy. As a result, party officials at the regional level tended to take positions that were in line with the policies of the central party executives and afraid to oppose them. In many cases, violations by party officials at the primary level have resulted in sanctions, even resulted in dismissal. The case of Tarmidi Suhardjo, who is the Head of PDIP Regional Representatives of Jakarta Special Region (DKI) who also serves as the Head of DPRD (Provincial Legislative Council) in DKI Jakarta and finally was dismissed from his position as a Chief in the legislative institution due to differences of opinion with DPP PDIP regarding the nomination for the Governor Election of DKI Jakarta for the 2002-2007 period is an example. Next, the confusion over the nomination for the Governor Election of Central Java in the 2003-2008 period caused Mardiyo to withdraw as the Head of PDIP's Central Leadership Council (DPD) of Central Java, which is also caused by differences in views with Central Esecutive Board (DPP) PDIP.

The leadership domination of the major party also occurred in several other cases, for example, the dismissal of Ruhut Sitompul from a member of the Democratic party for supporting a different candidate from the DPP Democrats (PD) in the 2017 DKI Jakarta gubernatorial election (Ibrahim, 2018). Another case is the dismissal of Agus Gumiwang Kartasasmita, Nusron Wahid, and Poempida Hidayarulloh because they are different choice with the DPP Golkar in the 2014-2019 Presidential election (Syahni, 2014). The last case that also received the spotlight is the resignation of some of PKS cadres in the region as a result of internal divisions of the party suspected of being caused by ideological problems (Firmansyah, 2019; Budianto, 2018). The phenomenon of the resignation of PKS cadres is a result of the ideological struggle between the conservative faction and another faction that wants reform within the party. The result of the polemic in Justice Party (PK) was the removal of figures regarded as followers of Anis Matta by DPP PKS (Kresna, 2018). Regardless of the reason, in the cases mentioned above, it can be seen how DPP 's position is very central and dominant in making strategic policies including removing party cadres who have differing views both politically and ideologically.

\section{Implications For Indonesian Democracy}

Political parties are a fundamental entity in democracy (Imansyah, 2012) and therefore, will always be an issue that is always interesting to examine. However, it is interesting to discuss the relationship between political parties, especially the institutionalization of political parties and democracy. Some experts, for example, emphasize that the presence of a democratic government will not be possible without the presence of a competitive party system (Crotty, 1993). Huntington said that the primary condition towards a consolidated democracy is the institutionalization of general elections and the institutionalization of political parties. Referring to Huntington's opinion, the arguments of some circles who argue that Indonesia has 
entered the stage of a consolidated democracy and can help each other with an institutionalized party system (Budiatri, 2016) needs to re-examine.

The performance of political parties in post-New Order Indonesia clearly shows that the parties have failed to take advantage of the open political space during the reform era. An examination of the three dimensions of party institutionalization above is sufficient to justify this claim. Indeed, without reducing the role of political parties in Indonesia, which became increasingly central after the New Order, the series of problems presented by political parties is evidence that the institutionalization of political parties in Indonesia is still very weak. The function of political parties as a forum for the birth of quality public officials, including politicians makes them central in a representative democracy. In that context, the function of representation becomes crucial to notice because it links the people and the state. Then, the problem is that the political parties in post-reform Indonesia are preoccupied with internal conflicts which are exacerbated by not developing an ideal internal conflict resolution. In democracy, the idea of political parties in post-reform Indonesia shows atrocious symptoms, especially the thickening of oligarchy in the party body and the strengthening of the role of figures in the party which leads to the subordination of the party by the figures. In the dimension of the relationship between parties and voters, it also shows the weak institutionalization of political parties because of the high electoral volatility (Nasir, 2016) which reflects the parties' rootlessness in society.

Thus, referring to the concept of consolidated democracy according to 0, Donnel and Schmitter as a process of combining several elements of democracy to create political democratization where the elements include political institutions or institutions including political parties (Nugroho, 2001). Huntington's opinion also requires the institutionalization of parties as a condition for the consolidation of democracy; thus, Indonesian democracy has not yet reached the consolidation stage.

\section{CONCLUSION}

Amid the heavy responsibilities assigned to them, political parties in Indonesia are instead busy with their internal problems. Political parties fail to reform, especially in carrying out the process of institutionalization and the result trapped in the practice of party management that is not ideal. Therefore, Indonesia's opportunity to move out of the transition phase of democracy towards a consolidated democracy is challenging to be actualized, chiefly it is given the failure of political parties to institutionalize. Although the institutionalization of political parties is not the only indicator that leads to a consolidated democracy, however, because of the party's position is fundamental to democracy, the establishment of a consolidated democracy cannot be less than that.

How long Indonesia will confine in the transition phase of democracy, of course, it depends on the seriousness of political parties are to make improvements on the one hand and of course other political elements that also influence on improving the quality of democracy. For this reason, the agenda of institutionalizing political parties must be echoed loudly, especially by party officials, especially regarding ideal political party governance as a form of a strong commitment to democracy. For future regulations, simplifying political parties is necessary by tightening the requirements for the party 
establishment and through the institutionalization of a much higher parliamentary threshold.

\section{REFERENCES}

Admojo, T. (2016). Peran Partai Oposisi di Parlemen Pasca Pemilu Presiden 2014. Jurnal Politik, 1(2), 283-315. https://doi.org/10.7454/jp.v1i2.18

Ambardi, K. (2009). Mengungkap Politik Kartel. Jakarta: Kepustakaan Populer Gramedia.

Aminuddin, M. F. (2016). Electoral System and Party Dimension Assessment in Democratic Indonesia. Jurnal Ilmu Sosial dan Ilmu Politik, 20(1), 1-15. https://doi.org/10.22146/jsp.17956

Budi, A. (2013). Membongkar Veto Player dalam Politik Kepartaian Indonesia Menuju Pemilu 2014. Jurnal Ilmu Sosial dan Ilmu Politik, 17(1), 51-66. https://doi.org/10.22146/jsp.10893

Budianto, E. E. (2018). Kader PKS Mojokerto Ramai-ramai Mengundurkan Diri. detiknews: https://news.detik.com/berita-jawa-timur/d-4273094/kader-pksmojokerto-ramai-ramai-mengundurkan-diri.

Budiatri, A. P. (2016). Pelembagaan Sistem Kepartaian Di Bawah Sistem Demokrasi Indonesia (1998-Sekarang). Jurnal Penelitian Politik, 12(1), 33-55.

Budiatri, A. P., Haris, S., Romli, L., Nuryanti, S., Nurhasim, M., Darmawan, D., \& Hanafi, R. I. (2017). Faksi dan Konflik Internal Partai-Partai Politik di Indonesia Era Reformasi. Jurnal Penelitian Politik, 14(2), 261-275. https://doi.org/10.14203/jpp.v14i2.726

Crotty, W. (1993). Notes on the Study of Political Parties in the Third World. American Review of Politics, 14, 659-694. https://doi.org/10.15763/issn.23747781.1993.14.0.659-694

Dwipayana, A. A. (2009). Demokrasi Biaya Tinggi: Dimensi Ekonomi dalam Proses Demokrasi Elektoral di Indonesia Pasca Orde Baru. Jurnal Ilmu Sosial dan Ilmu Politik, 12(3), 257-279. https://doi.org/10.22146/jsp.10971

Fauzi, I. (2018). Puluhan Pengurus PKS Langkat Mengundurkan Diri. Antaranews: https://sumut.antaranews.com/berita/180893/puluhan-pengurus-pks-langkatmengundurkan-diri\#.

Feith, H. (2006). The Decline of Constitutional Democracy in Indonesia: Jakarta: Equinox Publishing.

Firmadi, S., \& Purwaningsih, T. (2017). Analisis Institusionalisasi Partai Politik Pada Pemilu Legislatif Tahun 2014. Journal of Governance and Public Policy, 3(3), 446465.

Firmansyah, T. (2019). Ratusan Kader PKS Kabupaten Tangerang Mengundurkan Diri. , Republika.co.id:

https://www.republika.co.id/berita/pxn1i6377/nasional/politik/19/09/10/pxlx3 2377-ratusan-kader-pks-kabupaten-tangerang-mengundurkan-diri.

Haboddin, M. (2011). Konflik Partai: Perbandingan antara PKB dan PDIP. Governance, $1(2), 82-103$. 
Hanta Yuda, A. (2009). Partai Politik, Pemilu, Koalisi Pemerintahan dan Prospek Demokrasi. Indonesia: Journal the Indonesian Institute Center for Public Policy Research, 79-96.

Haris, S. (2014). Partai, Pemilu, dan Parlemen Era Reformasi: Sleman: Yayasan Pustaka Obor Indonesia.

Haughton, T., \& Deegan-Krause, K. (2015). Hurricane Season: Systems of Instability in Central and East European Party Politics. East European Politics and Societies, 29(1), 61-80. https://doi.org/10.1177\%2F0888325414566072

Hermawan, B. (2018). Ratusan Pengurus dan Anggota PKS se-Bali Mengundurkan Diri, republika.co.id:

https://www.republika.co.id/berita/nasional/politik/18/09/28/pfrgh3354ratusan-pengurus-dan-anggota-pks-sebali-mengundurkan-diri.

Hidayat, S. (2017). An Islamic Party in Urban Local Politics: The PKS Candidacy at the 2012 Jakarta Gubernatorial Election. Jurnal Politik, 2(1), 5-40. https://doi.org/10.7454/jp.v2i1.80

Huntington, S. P. (1968). Political Order in Changing. Societies. London: Yale University Press.

Ibrahim, G. M., \& Maharani, T. (2018). Demokrat Sudah Tak Akui Ruhut Sitompul sebagai Kader, detiknews: https://news.detik.com/berita/d-3998559/demokratsudah-tak-akui-ruhut-sitompul-sebagai-kader.

Imansyah, T. (2012). Regulasi partai politik dalam mewujudkan penguatan peran dan fungsi kelembagaan partai politik. Jurnal Rechts Vinding: Media Pembinaan Hukum Nasional, 1(3), 375-395. http://dx.doi.org/10.33331/rechtsvinding.v1i3.91

IMD. (2006). Suatu Kerangka Kerja Pengembangan Partai Politik yang Demokratis. Den Haag

Kirom. (2019). Diganti Cuma Lewat Surat, 300 Pengurus DPD PKS Tangerang Mundur. , Merdeka.com: https://www.merdeka.com/politik/diganti-cuma-lewat-surat-300pengurus-dpd-pks-tangerang-mundur.html.

Kresna, M. (2018). Konflik Internal PKS: Membuka Lagi Faksi Keadilan \& Faksi Sejahtera , tirto.id: https://tirto.id/konflik-internal-pks-membuka-lagi-faksi-keadilan-.

Lay, C. (2019). Melawan Negara: PDI 1973-1986 (Edisi Revisi). Yogyakarta: Polgov.

Lestari, Y. S. (2017). Kartel Politik dan Korupsi Politik di Indonesia. Pandecta: Jurnal Penelitian Ilmu Hukum (Research Law Journal), 12(1), 67-75. https://doi.org/10.15294/pandecta.v12i1.7820

Mahardika, A. G. (2019). Penerapan Pemilihan Pendahuluan Sebagai Upaya Menciptakan Pelembagaan Partai Politik yang Demokratis. JWP (Jurnal Wacana Politik), 4(2), 122-132. https://doi.org/10.24198/jwp.v4i2.23504

Mainwaring, S. (2016). Party System Institutionalization, Party Collapse and Party Building. Government and Opposition, 51(4), 691-716. https://doi.org/10.1017/gov.2016.21 
Mainwaring, S., \& Scully, T. (1995). Building Democratic Institutions: Party Systems in Latin America: Stanford: Stanford University Press.

Mangestuti, A. G. (2010). Pelembagaan Politik Partai. Jurnal Politik Indonesia, 1 (1), 2533.

Mietzner, M. (2013). Money, Power, and Ideology: Political Parties in Post-Authoritarian Indonesia. Singapore: NUS Press.

Muhtadi, B. (2013). Politik uang dan dinamika elektoral di Indonesia: Sebuah kajian awal interaksi antara "Party-ID" dan Patron-Klien. Jurnal Penelitian Politik, 10(1), 41-57.

Nasir, N. (2016). Electoral Volatility dalam Perspektif Kelembagaan Partai politik di Indonesia: Sebuah Analisis Hubungan Partai Politik dengan Konstituen. JPP (Jurnal Politik Profetik), 4(1). https://doi.org/10.24252/profetik.v4i1a3

Nathaniel, F. (2019). Sering Dilanda Konflik Internal adalah Rahasia Kekuatan Golkar. , tirto.id: https://tirto.id/sering-dilanda-konflik-internal-adalah-rahasia-kekuatangolkar-ekSz.

Noor, F. (2015). Perpecahan \& Solidaritas Partai Islam di Indonesia: Kasus PKB dan PKS di Dekade Awal reformasi. Jakarta: LIPI Press.

Nugroho, K. (2001). Konsolidasi Demokrasi. Masyarakat, Kebudayaan dan Politik 2 (April), 25-34.

Primadi, A., \& Purwaningsih, T. (2019). Institusionalisasi Partai Politik dalam Pilkada 2017 (Studi Kasus: Partai Golkar Provinsi Kepulauan Bangka Belitung). Journal of Government and Civil Society, 3(1), 63-78. http://dx.doi.org/10.31000/jgcs.v3i1.1099

Ramadhan, B. (2014). Romahurmuziy: Muktamar PPP di Surabaya Sah. Republika.co.id: https://republika.co.id/berita/ndg1v2/romahurmuziy-muktamar-ppp-disurabaya-sah

Randall, V., \& Svåsand, L. (2002). Party Institutionalization in New Democracies. Party Politics, 8(1), 5-29. https://doi.org/10.1177\%2F1354068802008001001

Ridha, M. (2016). Dilema Pelembagaan Partai Golongan Karya (Golkar) di Tingkat Lokal: Fenomena Politik Klan. CosmoGov: Jurnal Ilmu Pemerintahan, 2(1), 160-182. https://doi.org/10.24198/cosmogov.v2i1.11855

Ristyawati, A. (2019). Penguatan Partai Politik sebagai Salah Satu Bentuk Pengadministrasian dan Pelembagaan Sistem Demokrasi. Administrative Law \& Governance Journal, 2(4), 710-120. https://doi.org/10.14710/alj.v2i4.710\%20$\% 20120$

Roberts, K. M. (2017). State of the Field: Party Politics in Hard Times: Comparative Perspectives on the European and Latin American Economic Crises. European Journal of Political Research, 56(2), 218-233. https://doi.org/10.1111/14756765.12191.

Romli, L. (2016). Masalah Kelembagaan Partai Politik di Indonesia Pasca-Orde Baru. Jurnal Penelitian Politik, 5(1), 21-30. https://doi.org/10.14203/jpp.v5i1.494 
Sadewo, J. (2014). Ini Muktamar VIII PPP yang Sah, Hasil Putusan Sidang Mahkamah Partai. Republika.co.id: https://nasional.republika.co.id/berita/ndj3vw/inimuktamar-viii-ppp-yang-sah-hasil-putusan-sidang-mahkamah-partai

Sihidi, I. T., Khanifah, L. N., \& Romadhan, A. A. (2019). Relasi Politik Uang dan Party-ID di Indonesia.

204-220. https://doi.org/10.24198/cosmogov.v5i2.23293

Slater, D., \& Simmons, E. (2013). Coping by Colluding: Political Uncertainty and Promiscuous Powersharing in Indonesia and Bolivia. Comparative Political Studies, 46(11), 1366-1393. https://doi.org/10.1177\%2F0010414012453447

Syahni, M. (2014). Golkar: Pemecatan 3 Kader Sesuai Aturan, Kompas.com: https://nasional.kompas.com/read/2014/06/24/1316524/Golkar.Pemecatan.3.Ka der.Sesuai.Aturan.

Tan, P. J. (2002). Anti-Party Reaction in Indonesia: Causes and Implications. Contemporary Southeast Asia, 484-508.

Tempo.co. (2016). Kalah di PTUN, Romahurmuziy PPP: Masih Banyak Jalan. Tempo.co: https://nasional.tempo.co/read/822258/kalah-di-ptun-romahurmuziy-pppmasih-banyak-jalan/full\&view $=o k$.

Tempo.co. (2017). Pasca-Putusan MA, PPP Kubu Romahurmuziy Ajak Djan Faridz Gabung, Tempo.co: https://nasional.tempo.co/read/1045170/pasca-putusan-mappp-kubu-romahurmuziy-ajak-djan-faridz-gabung/full\&view=ok.

Tempo.co. (2018). Konflik di Internal PKS Meruncing, Tempo.co: https://koran.tempo.co/read/laporan-utama/432341/konflik-di-internal-pksmeruncing.

Vasilopoulou, S. (2018). The Party Politics of Euroscepticism in Times of Crisis: The Case of Greece. Politics, 38(3), 311-326. https://doi.org/10.1177\%2F0263395718770599

Winters, J. A. (2011). Oligarki. Jakarta: PT. Gramedia Pustaka Utama.

Wonka, A. (2016). The Party Politics of the Euro Crisis in the German Bundestag: Frames, Positions and Salience. West European Politics, 39(1), 125-144. https://doi.org/10.1080/01402382.2015.1081512

Yumitro, G. (2013). Partai Islam dalam Dinamika Demokrasi di Indonesia. Jurnal Ilmu Sosial dan Ilmu Politik, 17(1), 35-50. https://doi.org/10.22146/jsp.10892 